\title{
ПСИХОЛОГІЧНІ ОСОБЛИВОСТІ РОЗВИТКУ КОГНІТИВНОГО КОМПОНЕНТА САМОСТІЙНОСТІ СУЧАСНИХ ПІДЛІТКІВ
}

\author{
Любов Долинська \\ кандидат психологічних наук, професор, завідувач кафедри психології \\ Національний педагогічний університет імені М. П. Драгоманова \\ 01601, м. Київ, вул. Пирогова, 9 \\ Lbvdolinska@gmail.com, https://orcid.org/0000-0002-1817-1102 \\ Дар'я Поліщук \\ аспірантка кафедри психології \\ Національний педагогічний університет імені М. П. Драгоманова \\ 01601, м. Київ, вул. Пирогова, 9 \\ daria_polishchuk@ukr.net, https://orcid.org/0000-0001-6400-624X
}

\begin{abstract}
Анотація
В статті обгрунтовується актуальність і доцільність дослідження феномена самостійності сучасних підлітків. Зазначено, що досліджуване поняття є багатокомпонентним утворенням, a, відтак, у його структурі виокремлено 4 компоненти: когнітивний, мотиваційно-ціннісний, поведінковий та емоційний. Статтю присвячено вивченню когнітивного компонента феномена самостійності сучасних підлітків. Метою дослідження $є$ визначення рівня розвитку когнітивного компонента через його складові - креативність, яка характеризує бажання людини генерувати нові ідеї та втілювати їх у життя, а також невпинно шукати можливості для розвитку, та рефлексивність, завдяки якій підліток спроможний усвідомити результати власних дій і вчинків, підбити підсумки та, за необхідності, скорегувати свої дії в правильне русло. В теоретичній частині подано аналіз основних підходів зарубіжних та вітчизняних вчених до проблеми розвитку когнітивного компонента феномена самостійності в сучасній психології. Емпірично визначено особливості розвитку показників когнітивного компоненту креативності сучасних підлітків, зокрема прояву допитливості, уяви, складності вирішуваних завдань і схильності до ризику. Виявлено переважання середнього рівня уяви, складності вирішуваних завдань, схильності до ризику, компонент допитливості займає рівень вище середнього в досліджуваних, що $\epsilon$ віковою характеристикою підлітків. Досліджено і проаналізовано рівень розвитку рефлексивності сучасних підлітків. Визначено переважання низького (який характеризується труднощами у плануванні своєї діяльності, відсутністю здатності до аналізу своїх помилок, неможливістю використовувати здобутий досвід у вирішенні складних ситуацій, труднощами у регулюванні власної поведінки) та середнього рівня розвитку рефлексивності (ознаками якого є здатність до планування своїх дій та їх аналіз, а також аналіз учинків інших людей, проте рефлексивні процеси мають нерегулярний характер, а рефлексивний аналіз є поверховим). Обгрунтовано значущість креативності та рефлексивності, як показників когнітивного компонента креативності в загальній структурі самостійності, та її розвитку впродовж підліткового віку.
\end{abstract}

Ключові слова: когнітивний компонент, самостійність, саморегуляція, креативність, уява, інтелект, рефлексія, підліток. 


\section{Вступ}

В системі сучасної психологічної науки визначено роль самостійності як особистісної якості, як показника індивідуальності. Особистісна самостійність є важливим засобом соціалізації, яка проявляється в здатності ставити та реалізовувати цілі, корегувати їх за необхідності, оцінювати ризики та свої можливості у ставленні до інших людей та обставин дійсності. Феномен самостійності $€$ певним інтегратором, що містить незалежність, автономність, самобутність особистості.

Згідно досліджень вікової психології, суттєвого розвитку самостійність зазнає у підлітковий період. Саме в підлітковому віці виникає так зване «почуття дорослості», яке виявляється в загостренні вимог до близьких, потребі прислухатися до їх думки і сприймати їх як рівних, вимагаючи для себе однакових прав 3 дорослими. Оскільки не кожна доросла людина спроможна аналізувати свій життєвий досвід i не повторювати помилок, прогнозувати розвиток подій, мати здатність і готовність приймати рішення, то, аналізуючи розвиток особистості підлітка, можна стверджувати, що саме в межах досліджуваного вікового періоду формується мислення автономної і самостійної людини, яке визначає подальший розвиток особистості.

За визначенням Е.Ю. Алієвої (Алієва, 2017), феномен самостійності є інтегрованою якістю особистості, яка проявляється в ініціативності, критичності, почутті особистісної відповідальності, адекватній самооцінці, рішучості, сміливості, наполегливості, здатності до ризику, емоційній стійкості тощо. Цей перелік засвідчує, що досліджуваний феномен $є$ багатокомпонентним утворенням. В нашому дослідженні ми приймаємо підхід Е.Ю. Алієвої щодо чотирикомпонентної структури самостійності, а саме: когнітивний, мотиваційноціннісний, емоційний і поведінковий компоненти.

Статтю присвячено емпіричному вивченню когнітивного компонента самостійності, який презентований креативністю - якістю, що дозволяє людині аналізувати та знаходити різні шляхи вирішення проблеми та рефлексивністю, що відповідає за аналіз власних вчинків та дій і усвідомлення необхідності їх корекції (Алієва, 2017).

В межах теми нашої статті зупинимося на наявних психологічних дослідженнях когнітивного аспекту феномена самостійності. В зарубіжних дослідженнях цей аспект проблеми зацікавив німецьких вчених. Зокрема психолог Е. Дрішнер розглядає самостійність як найвищу перспективну ціль виховання, в процесі якої особистість «виводиться» із зони незрілості, стає більш незалежною і розширює можливості життя, керуючись при цьому власним розумом (Drieschner, 2007). Дослідники (Suprinovič, Schneck \& Kay, 2016; Manske \& Scheffelmeier, 2015) схвильовані тим фактом, що останнім часом самостійність все частіше припиняе свій розвиток на ранніх стадіях розвитку особистості. Згідно 3 останніми дослідженнями, більше 40\% дорослих людей не виявляють ознак самостійності в суспільній поведінці та в роботі, яка вимагає прийняття відповідальних рішень. Вони віддають перевагу роботі під чітким керівництвом наставника, який вказує, що робити і як, або ж взагалі обирають безробіття через острах покладатися на власний інтелектуальний потенціал $\mathrm{i}$ набувати досвід вирішення проблемних питань.

Зазначене зумовлює необхідність пошуку шляхів більш інтенсивного розвитку самостійності особистості в період іiі розвитку з урахуванням вікових особливостей дитини.

Взаємозв’язок розвитку самостійності з інтелектом також простежується в працях I.C. Кона (Кон, 1992). Вчений дотримується думки, що зростання самостійності залежить від рівня розвитку самосвідомості молодої людини, усвідомлення стійкості образу «Я», що 
неодмінно пов'язано 3 рівнем розвитку інтелекту. На думку дослідника, поняття «самостійність» містить три взаємопов'язані якості: незалежність, як здатність самому приймати рішення, не потребуючи підказки; відповідальність, бути готовим відповідати за наслідки своїх вчинків; впевненість у соціальній можливості і моральній правильності такої поведінки. І.С. Кон розглядає індивідуально-психологічні передумови самостійності як досить стійкі, але, водночас підкреслює, що вони не $є$ незмінними. Він зауважує, що на основі досліджень про те, що ранній вік дитини має велике значення в розвитку і становленні особистості, були помилково зроблені висновки, що ранній вік дитини раз і назавжди визначає якості дорослої людини. Насправді, на думку дослідника, в дитинстві закладаються лише передумови і можливості майбутнього розвитку, а наскільки вони зможуть реалізуватися - залежить від подальшого життєвого досвіду й оточення. Вчений відзначає, що для виховання самостійності потрібен гнучкий баланс прав і обов'язків дитини. Жорстка дисципліна, яка не передбачає індивідуальних варіацій, так само протипоказана ій, як i аморфна вседозволеність і теплична атмосфера, в якій не може виховуватися сильна воля. Самостійність формується всім стилем життя, який спонукає особистість з раннього дитинства здійснювати вчинки і брати за них відповідальність. I хоча, на думку I.С. Кона, самостійні люди постійно збурюють чий-небудь спокій, без людської самостійності $\epsilon$ неможливим розвиток суспільства, адже «спиратися можна лише на те, що чинить супротив» (Кон, 1992: 271).

Вчені Г. Крайг і Д. Бокум (Крайг \& Бокум, 2005) також відстежували зв'язки між рівнем розвитку самостійності та інтелекту. Дослідники встановили, що люди середнього і старшого віку, робота яких пов'язана 3 прийняттям самостійних рішень, виявленням ініціативи та вирішенням складних завдань, демонструють високі інтелектуальні здібності.

Вчений О.К. Осницький (Осницький, 2010), досліджуючи особистісні якості, які визначають рівень розвитку самостійності, виявив, що загалом рівень сформованості структурно-компонентних вмінь саморегуляції (пов'язаних із визначенням цілі, моделюванням умов, програмуванням дій, оцінкою результатів і їх корекцією) в учнів 3 високою і середньою успішністю значно вище, ніж в учнів 3 низькою успішністю. Дослідження, проведені О.К. Осницьким, свідчать про значні відмінності у розвитку самостійності та саморегуляції групи дітей з низьким рівнем розумового розвитку від інших учнів. Ці підлітки мають більш низькі показники саморегуляції загалом, сформованості структурно-компонентних вмінь, а також рівня пізнавальної активності.

На думку дослідника С.Г. Касвінова (Касвінов, 2013), достатньо високий рівень складності завдань, які вирішуються підлітками, є вагомим фактором, що сприяє розвитку самостійності (саморегуляції). Розвиток самостійності відбувається під впливом середовища, передусім - навчання (виховання), що здійснюється в зоні найближчого розвитку.

Узагальнення досліджень когнітивної сторони феномена самостійності дозволяє зробити висновок, що самостійна людина має, як правило, більш високий інтелектуальний рівень розвитку, що допомагає їй при вирішенні складних життєвих завдань покладатися на власні сили; вона не боїться проявляти креативність, висувати нові ідеї та адекватно реагує на об'єктивну критику, оскільки вміє проаналізувати свої вчинки та дії.

Це дозволяє нам розглядати когнітивний компонент самостійності підлітків, як такий, що містить особистісні прояви як показники - креативність і рефлексію. За нашим припущенням, саме ці показники когнітивного компоненту $є$ провідними у розвитку самостійності, оскільки креативність необхідна людині для генерування нових ідей та 
втілення їх у життя, створення нових можливостей для розвитку і руху вперед, а завдяки рефлексії підліток може усвідомити результати власної діяльності, підвести підсумки i, відповідно, скорегувати ії на правильний шлях.

Мета дослідження: емпірично вивчити психологічні особливості розвитку когнітивного компонента самостійності підлітків. Часткова робоча гіпотеза нашого дослідження полягала в наявності прямого взаємозв'язку між розвитком когнітивного компонента і рівнем розвитку самостійності підлітків загалом. Завдання дослідження: 1) підібрати пакет діагностичних методик для вивчення когнітивного компонента самостійності підлітків; 2) виявити особливості прояву креативності підлітків; 3) дослідити сформованість рефлексивності підлітків.

\section{Методи дослідження}

Для досягнення мети нашої дослідницької роботи застосовувалися діагностичні та статистичні методи. Для дослідження особливостей розвитку креативності, як показника когнітивного компонента, самостійності підлітків використовувалася методика «Діагностика особистісної креативності» О.Є. Тунік (Тунік, 2002), яка дозволяє виокремити 4 складові творчої особистості: допитливість, уява, складність і схильність до ризику та визначити 5 рівнів розвитку креативності: низький, понижений, середній, підвищений і високий. Для діагностики рефлексивності застосовувалася «Методика рефлективності» А.В. Карпова (Карпов, 2003), яка дозволяє схарактеризувати 3 рівні розвитку досліджуваного феномена: низький, середній та високий.

Дослідження проводилося в закладах загальної середньої освіти № 215 і № 281 м. Києва. Загальна вибірка досліджуваних склала 296 осіб, серед яких 137 дівчаток і 159 хлопців, учнів 6-9 класів.

Етапи емпіричного дослідження:

1. Аналіз досліджень когнітивного компонента самостійності, обгрунтування його показників і підбір діагностичних методик з метою їх емпіричного вивчення.

2. Емпіричне вивчення особливостей прояву креативності та рефлексивності, як показників когнітивного компонента самостійності.

3. Кількісний та якісний аналіз одержаних даних щодо особливостей розвитку когнітивного компонента самостійності.

\section{Результати та дискусії}

Отже, після проведення емпіричного дослідження з розвитку креативності підлітків, нами були отримані кількісні дані, які подано на рис. 1. Згідно з рисунком, можемо констатувати таке: низький рівень креативності властивий $10,47 \%$, понижений рівень 19,93\%, середній рівень характеризується найвищими показниками - 37,17\%, підвищений рівень мають 31,08\% досліджених, а високий посідають лише 1,35\% підлітків.

Подані на рис. 1 дані свідчать про те, що у підлітків переважає середній рівень розвитку креативності. Це може бути свідченням того, що сучасні підлітки не мають високої потреби генерувати ідеї, створювати нове, в них занижена потреба у пізнанні, а у шкільному навчанні переважає репродуктивний спосіб відтворення навчального матеріалу. Проте, найбільше турбує той факт, що більше третини підлітків мають низький та понижений рівні розвитку креативності, які характеризуються відсутністю зацікавленості у пізнанні й пошуку 
нових шляхів мислення, слабкою уявою, небажанням вивчати твори мистецтва i розширювати власне світобачення.

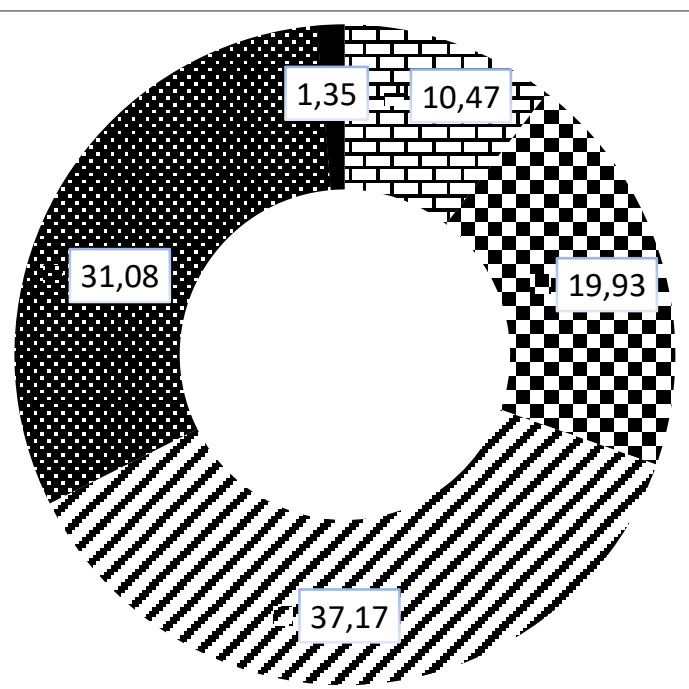

+ Низький

- Понижений

- Середній

$\mathbf{8}$ Підвищений

- Високий

Рис. 1. Кількісні показники рівнів розвитку особистісної креативності сучасних підлітків (у \%)

Для того, щоб зрозуміти отримані дані, розглянемо розвиток креативності за іiі складовими (табл. 1), які визначено за методикою О.Є. Тунік.

Таблиия 1

Кількісні показники рівнів розвитку складових креативності (у \%)

\begin{tabular}{|c|c|c|c|c|c|}
\hline \multirow{2}{*}{$\begin{array}{c}\text { Складові } \\
\text { креативності }\end{array}$} & \multicolumn{5}{|c|}{ Рівні } \\
\cline { 2 - 6 } Допитливість & 5,07 & 8,45 & 30,4 & 36,15 & 19,93 \\
\hline Дяий & Занижений & Середній & Підвищений & Високий \\
\hline Уява & 6,76 & 17,23 & 40,88 & 29,73 & 5,4 \\
\hline Ризик & 3,72 & 16,55 & 37,84 & 36,15 & 5,74 \\
\hline Складність & 7,43 & 23,65 & 44,59 & 23,99 & 0,34 \\
\hline
\end{tabular}

Допитливість, як складова креативності, означає бажання зрозуміти світ, дізнатись нову інформацію про довкілля. Допитливі люди 3 легкістю сприймають нові ідеї, мають високу мотивацію до досягнень, а також високий інтелектуальний рівень, оскільки ступінь нашої допитливості неодмінно пов'язаний з нашими знаннями. Підтвердженням цих суджень $\epsilon$ висловлювання вченого П. Бірі про те, що «навчання починається 3 допитливості» (Bieri, 2017: 8). У своїй книзі «Як бути освіченою людиною» вчений досліджує питання впливу різноманітних факторів на процес навчання. Одним з провідних автор вважає допитливість і наголошує на тому, що навчання є двостороннім процесом - спочатку ми зацікавлюємося світом і пізнаємо його, а потім дізнаємося як вчитися.

Аналізуючи рівень розвитку підліткової допитливості, ми дійшли висновку, що вказаний компонент креативності перебуває в найвищому діапазоні на середньому $(30,4 \%)$ та підвищеному рівнях (36,15\%). Низький рівень притаманний 5,07\% підлітків, занижений мають 8,45\% досліджуваних, а високого рівня допитливості сягають 19,93\% досліджуваних підлітків. Достатньо хороші показники, на нашу думку, порівняно із загальними показниками креативності, зумовлені активізацією зацікавленості підлітків різноманітними 
аспектами життя - минуле і майбутнє, життя і смерть, соціальні та екологічні теми, дружні стосунки тощо.

Наступним компонентом креативності є уява. Вплив уяви на розвиток особистості доведено багатьма дослідженнями і це $є$ незаперечним фактом. Уява сприяє розвитку інтелекту, є основою пізнавальної діяльності та виховання творчої особистості, сприяє саморозкриттю і особистісному самовдосконаленню. В своїй уяві підліток вибудовує образ свого майбутнього дорослого життя, створює певні моделі поведінки, вчиться вирішувати різноманітні ситуації тощо. А допомагає йому в цьому, на думку дослідниці Дж. Бланд, ніщо інше, як читання. Оскільки, читаючи, ми не лише отримуємо задоволення, а ще й вчимося вирішувати складні і нестандартні задачі, навчаємось міжособистісним комунікаціям, а наша уява активно працює над створенням образу. Отже, за Дж. Бланд, «задоволення від читання тісно пов’язано із задоволенням від створення» (Bland, 2013: 160).

Згідно даних табл. 1, найвищими показниками характеризується середній рівень розвитку уяви у підлітків (40,88\%), наступний за ним - підвищений рівень, показники якого сягають 29,73\%. I хоча високого рівня розвитку сягають лише 5,4\%, можна констатувати загалом хороші показники. Низький рівень розвитку притаманний лише $6,76 \%$ підліткам, і ця група дітей вимагає окремого вивчення, оскільки слабка уява викликає труднощі у вирішенні мисленнєвих задач, які вимагають вміння відображати в своїй уяві конкретні ситуації. Низький рівень розвитку уяви призводить до неможливості проводити різностороннє в емоційному плані життя.

Наступна складова креативності - це складність вирімуваних завдань. Означеною категорією вимірюється зацікавленість досліджуваного в складних речах та ідеях, такий підліток любить вивчати сутність речей без сторонньої допомоги, наполегливий у досягненні цілі. Іншими словами дана характеристика може показати, наскільки підліток вірить в себе. Як бачимо з табл.1, переважна більшість підлітків (44,59\%) посідають середній рівень у в категорії складності вирішуваних завдань. Занижений та підвищений рівень складності вирішуваних завдань обирають майже по чверті всіх підлітків (23,65\% та 23,99\% відповідно). Низький рівень складності притаманний 7,43\% досліджуваних, а от високий рівень обирають лише 0,34\% підлітків. Одержані результати свідчать про те, що частина підлітків не завжди готова обирати та вирішувати складні життєві завдання, не мають великого бажання долати перешкоди для досягнення своєї мети. За нашим припущенням, позитивні результати 3 підвищення рівня цієї складової могла б дати робота з такими чинниками, як самооцінка та рівень домагань.

Наступним компонентом креативності $є$ така якість, як схильність до ризику. Дослідник Т. Кюльман (Kühlman, 2009) переконаний, що схильність до ризику формується під впливом культурного середовища, в якому проживає індивід. I хоча цей вплив не $є$ очевидним, проте культура формує наше сприймання, думки і почуття. Дані табл.1 свідчать про розвиток схильності до ризику в сучасних підлітків. Як бачимо, низький рівень ризику $є$ характерним для 3,72\% підлітків; занижений рівень властивий 16,55\%; середній рівень досягає найвищих позначок на рівні 37,84\%; підвищений зупиняється на позначці у 36,15\%; високий охоплює 5,74\% підлітків. Сумарний відсоток трьох останніх рівнів (79,73\%) свідчить про схильність підлітків до ризику, який є вагомим чинником у розвитку особистості підлітків, оскільки, ризикуючи, вони перевіряють межі власних можливостей, випробовують свої інтелектуальні сили, утверджують моральні якості тощо. 
Отже, аналізуючи рівень розвитку компонентів креативності, можемо констатувати, що досліджуваний феномен розвинений у сучасних підлітків за трьома з чотирьох категорій на середньому рівні і лише категорія допитливості сягає свого найвищого значення на підвищеному рівні. Це означає, що підлітки прагнуть до самостійності та мають певну гнучкість мислення, проте в них виникають труднощі 3 продукуванням ідей, які суттєво відрізняються від загальноприйнятих у соціумі, а також з удосконаленням довкілля та себе як особистості.

Оскільки у дослідженні взяли участь учні 6-9 класів, то це дало можливість відстежити розвиток компонентів креативності впродовж підлітковості (таб. 2).

Таблиия 2

Динамічні показники розвитку допитливості підлітків (у \%)

\begin{tabular}{|c|c|c|c|c|}
\hline \multirow{2}{*}{$\begin{array}{c}\text { Рівень } \\
\text { розвитку }\end{array}$} & 6 & 7 & 8 & 9 \\
\hline Низький & 4,71 & 8,64 & 3,16 & 2,86 \\
\hline Занижений & 10,58 & 6,17 & 4,21 & 20 \\
\hline Середній & 32,94 & 25,93 & 31,58 & 31,43 \\
\hline Підвищений & 30,59 & 39,51 & 42,1 & 25,71 \\
\hline Високий & 21,18 & 19,75 & 18,95 & 20 \\
\hline
\end{tabular}

Якщо відстежити динаміку розвитку підліткової допитливості (табл. 2), то можна побачити, що середній рівень розвитку допитливості впродовж цього періоду знижується 3 $32,94 \%$ до 31,43\%; підвищений рівень розвитку допитливості знижується 3 30,59\% до $25,71 \%$; високий рівень розвитку даної якості також знижується з 21,18\% до 20\%. Проте збільшується майже на 10\% занижений рівень розвитку допитливості (з 10,58\% у 6 класі до 20\% у 9 класі). Наведені дані викликають занепокоєння, оскільки чітко простежується спад підліткової допитливості. 3 одного боку, зрозуміло, що дитина підліткового віку певною мірою вже задовольнила свої запити на дослідження цього світу та «наситилась» знаннями, а з іншого - це може бути проявом апатії й відсутності психологічного благополуччя.

Таблиия 3

Динамічні показники розвитку уяви підлітків (у \%)

\begin{tabular}{|c|c|c|c|c|}
\hline \multirow{2}{*}{ Рівень } & \multicolumn{4}{|c|}{ Клас } \\
\cline { 2 - 5 } розвитку & 6 & 7 & 8 & 9 \\
\hline Низький & 8,14 & 7,5 & 3,19 & 11,11 \\
\hline Занижений & 16,28 & 11,25 & 20,21 & 41,67 \\
\hline Середній & 39,53 & 46,25 & 37,24 & 22,22 \\
\hline Підвищений & 24,42 & 31,25 & 36,17 & 0 \\
\hline Високий & 11,63 & 3,75 & 3,19 & \\
\hline
\end{tabular}

Аналізуючи розвиток уяви впродовж підлітковості (табл. 3), можемо констатувати таке: низький рівень розвитку уяви збільшується $38,14 \%$ до $11,11 \%$; занижений рівень розвитку збільшується з $16,28 \%$ до $25 \%$; середній рівень розвитку збільшується з $39,53 \%$ до $41,67 \%$. Знижується підвищений рівень розвитку з $24,42 \%$ до $22,22 \%$, а також високий рівень розвитку уяви з $11,63 \%$ до $0 \%$. Певний рівень зниження розвитку уяви впродовж навчання у школі є характерним, за даними психології, для дітей шкільного віку. Це пояснюється впливом навчального процесу, а саме насиченістю конкретних завдань для вирішення, при 
чому часу для фантазування стає дедалі менше. Проте наше занепокоєння викликає той факт, що на кінець 9 класу жоден 3 підлітків не має високого рівня розвитку уяви. Це може свідчити про звуження творчих можливостей шкільного навчання, надмірне шкільне навантаження, виснаження організму, що, в свою чергу, може зумовити гальмування загального особистісного зростання молодої людини.

Таблиця 4

Динамічні показники рівня складності вирішуваних завдань підлітків (у \%)

\begin{tabular}{|c|c|c|c|c|}
\hline \multirow{2}{*}{$\begin{array}{c}\text { Рівень } \\
\text { розвитку }\end{array}$} & \multicolumn{4}{|c|}{ Клас } \\
\cline { 1 - 5 } Низький & 4,65 & 7 & 8 & 9 \\
\hline Занижений & 32,56 & 4,94 & 8,42 & 17,65 \\
\hline Середній & 50 & 25,93 & 15,79 & 37,65 \\
\hline Підвищений & 11,63 & 21,97 & 45,26 & 29,41 \\
\hline Високий & 1,16 & 0 & 30,53 & 0 \\
\hline
\end{tabular}

Аналізуючи прояви рівня складності завдань (проблем) для вирішення в динаміці, можемо зробити такі висновки (табл. 4): впродовж періоду підлітковості значно зростає низький рівень цієї якості з 4,65\% у 6 класі до 17,65\% у 9 класі. Це означає, що 9-класники, стикаючись упродовж підліткового віку з різними складними ситуаціями, намагаються уникати їх. Занижений рівень знижується з 32,56\% у 6 класі до 17,65\% у 9 класі. Це може означати, що 14,91\% підлітків здобули впевненість у своїх силах і більше не обирають для себе занижені норми. Середній рівень складності завдань для вирішення знижується впродовж періоду підлітковості на 14,71\%, а підвищений - навпаки зростає на 17,78\%. Це може свідчити про те, що підлітки, які перебували на середньому рівні, переконані у власних можливостях і налаштовані більш рішуче, ніж на початку підліткового віку. Проте високий рівень складності проблем для вирішення властивий лише 1,16\% підлітків 6-го класу. Надалі спостерігаємо абсолютну відмову підлітків від обрання складних завдань для вирішення, що засвідчує необхідність розвитку в підлітків рівня домагань.

Таблиия 5

Динамічні показники рівня ризику підлітків (у \%)

\begin{tabular}{|c|c|c|c|c|}
\hline \multirow{2}{*}{$\begin{array}{c}\text { Рівень } \\
\text { розвитку }\end{array}$} & \multicolumn{4}{|c|}{ Клас } \\
\cline { 2 - 5 } & 6 & 7 & 8 & 9 \\
\hline Низький & 2,3 & 4,88 & 2,17 & 11,43 \\
\hline Занижений & 25,29 & 10,98 & 15,22 & 28,57 \\
\hline Середній & 40,23 & 39,02 & 38,04 & 48,57 \\
\hline Підвищений & 28,74 & 37,8 & 36,96 & 2,86 \\
\hline Високий & 3,44 & 7,32 & 7,61 & \\
\hline
\end{tabular}

Досліджуючи розвиток схильності до ризику в динаміці, ми отримали такі результати (табл. 5): низький рівень підвищується впродовж періоду підлітковості на 6,27\%; занижений рівень знижується на 13,86\%, а середній - на 11,66\%; підвищений рівень зростає на 19,83\%, а високий дещо знижується - на $0,58 \%$. Це означає, що до кінця підліткового віку в дітей значно підвищується схильність до ризику. Це може бути, як усвідомлення відокремлення від дорослих і бажання самостійно переживати гострі відчуття, що не завжди є безпечним у соціальному плані, а також слугувати мірою пізнавальних потреб підлітка. 


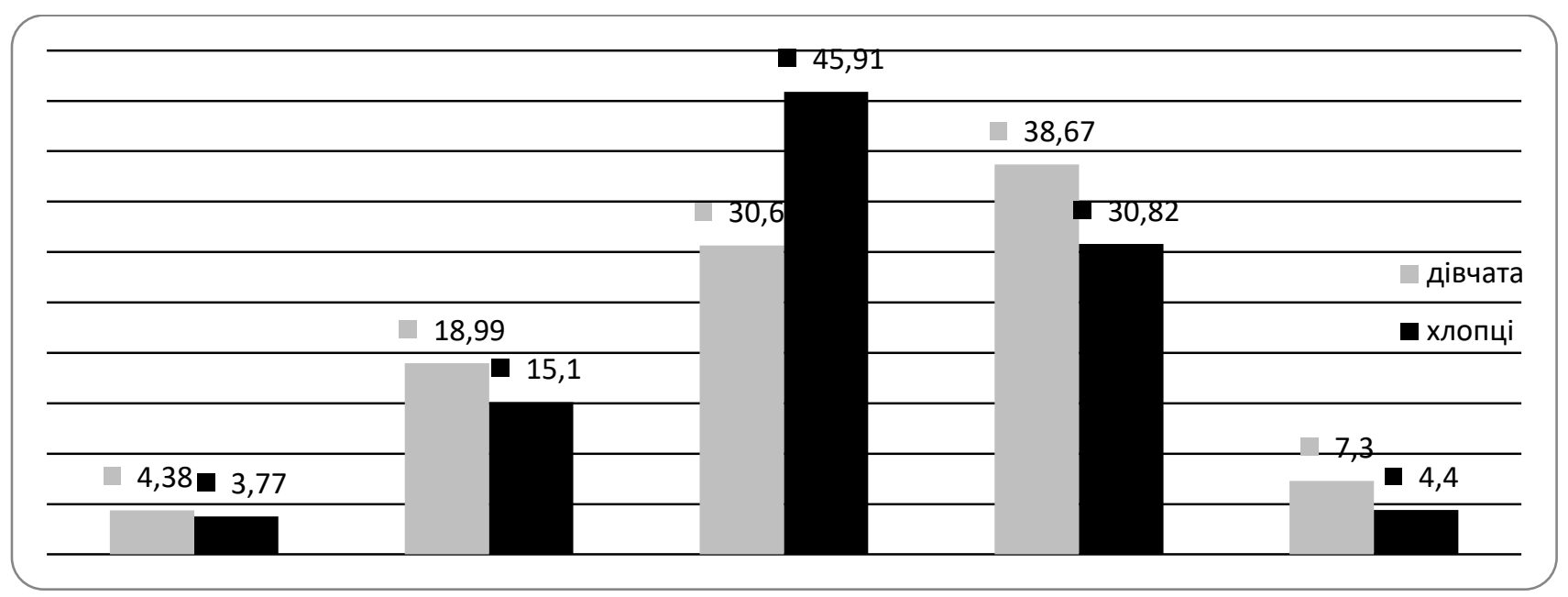

Рис. 2. Статеві відмінності схильності до ризику в підлітків (у \%)

Аналізуючи статеві особливості схильності до ризику сучасних підлітків (рис. 2), ми дійшли до висновку, що дівчата випереджають хлопців на таких рівнях, як підвищений (на 7,85\%) та високий (на 2,9\%). Отже, на противагу суспільній думці про те, що хлопці є більш ризиковими, виявилося, що дівчата більш схильні ставити перед собою високі цілі та намагатись їх досягнути, відстоювати свої ідеї, не зважаючи на реакцію інших, а також надають перевагу ризикнути, щоб дізнатися, що з цього вийде.

Складовою когнітивного компонента самостійності ми виокремили також здатність до рефлексивності, як спроможність людини осмислити та проаналізувати власні відчуття або дії за допомогою порівняння власного «Я» з іншими особистостями чи подіями. Рефлексивна людина перед тим, як діяти, розглядає гіпотези, осмислено приймає рішення, враховуючи його різноманітні варіанти.

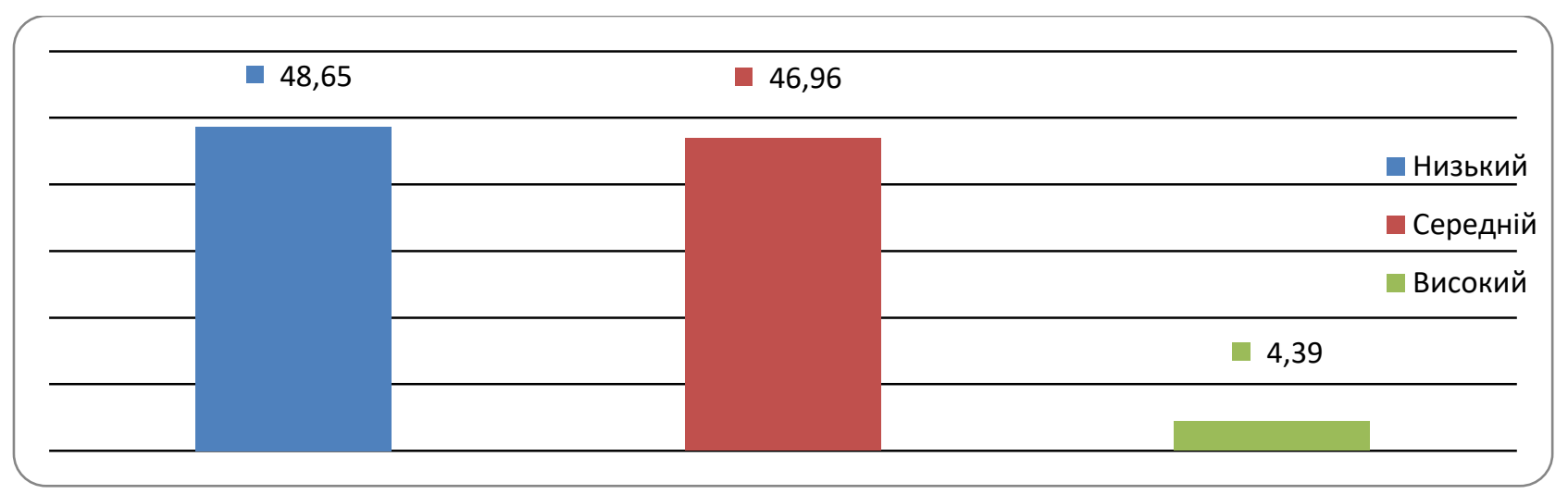

Рис. 3. Кількісні показники розвитку рівня рефлексивності сучасних підлітків (у \%)

За результатами проведеного дослідження (див. рис. 3) найвищі точки розвитку рефлексивності підлітків спостерігаються на низькому (48,65\%) і середньому $(46,96 \%)$ рівнях. Високого рівня розвитку рефлексивності досягли лише 4,39\% підлітків. Виявлені дані свідчать про те, що переважна частина підлітків не спроможна осмислити та проаналізувати власні почуття і дії, а також має значні труднощі з усвідомленням своїх позитивних i негативних якостей та яким чином вони можуть впливати на власні стосунки з людьми, які їх оточують. Зважаючи на значущість рефлексивності не лише, як показника когнітивного компонента самостійності, а й як механізму особистісного зростання, одержані дані 
викликають занепокоєння та зумовлюють потребу виявлення особливостей розвитку інших складових самостійності підлітків.

\section{Висновки}

Отже, вивчення когнітивного компонента самостійності уможливило такі висновки:

1. Когнітивна складова в структурі самостійності особистості характеризується такими показниками, як креативність (що характеризується оригінальністю та гнучкістю мислення, вмінням і бажанням підлітка генерувати нові ідеї та втілювати їх у життя, шукати можливості для саморозвитку) та рефлексивність (що означає вміння підлітка усвідомлювати результати власних дій і вчинків та на їх основі робити висновки задля уникнення помилок в майбутньому, та вміння аналізувати поведінку інших).

2. Складові креативності (допитливість, уява, схильність до ризику, складність завдань для вирішення) характеризуються середнім рівнем розвитку (окрім допитливості, що перебуває на підвищеному рівні розвитку). Це свідчить про те, що сучасні підлітки прагнуть пізнавати цей світ, проте недостатній рівень розвитку уяви, острах ризикувати та відмова від вирішення складних завдань через власну невпевненість не дають їм змоги реалізувати жагу до відкриттів, творчості й самоактуалізації власної особистості.

3. Підліткова здатність до рефлексивності характеризується низькими і середніми показниками, що також гальмує розвиток когнітивного компонента самостійності, оскільки підлітки не спроможні виявляти власні почуття та формулювати думки, аналізувати свої дії та вчинки. Отож, простежується низька здатність до аналізу свого внутрішнього світу і зовнішнього прояву в ньому, тобто усвідомлення себе в системі соціальних норм i суспільних стосунків.

Перспективи подальшого дослідження вбачаємо в проведенні аналізу розвитку мотиваційно-ціннісного, емоційного й поведінкового компонентів та дослідженні їхнього взаємозв'язку з феноменом самостійності.

\section{Література}

1. Алієва, Е.Ю. (2017). Психологічні чинники формування у студентів здатності до самостійного життєвого вибору. (Автореф. дис. канд. психол. наук). Київ.

2. Карпов, А.В. (2003). Рефлексивность как психическое свойство и методика ее диагностики. Психологический журнал, 5, 45-56.

3. Касвинов, С.Г. (2013). Система Выготского. Обучение и развитие детей и подростков. Харьков : Райдер.

4. Кон, И.С. (1992). Психология самостоятельности. Педагогика здоровья, 268-273.

5. Крайг, Г., \& Бокум, Д. (2005). Психология развития. Санкт-Петербург : Питер.

6. Осницкий, А.К. (2010). Психологические механизмы самостоятельности. Москва : Обнинск: ИГ-СОЦИН.

7. Туник, Е.Е. (2002). Диагностика личностной креативности. Н.П. Фетискин, В.В. Козлов \& Г.М. Мануйлов (Ред.), Социально-психологическая диагностика развития личности и малых групn (с. 59-64). Москва : Изд-во Института психотерапии.

8. Bieri, P. (2017). Wie wäre es, gebildet zu sein? München/Grünwald : Verlag Komplett Media $\mathrm{GmbH}$.

9. Bland, J. (2013). Children's literature and learner empowerment: children and teenagers. London : Bloomsbury Academic. 
10. Drieschner, E. (2007). Erziehungsziel „,Selbstständigkeit“. Grundlagen, Theorien und Probleme eines Leitbildes der Pädagogik. Wiesbaden : GWV Fachverlage GmbH.

11. Manske, A., \& Scheffelmeier, T. (2015). Werkverträge, Leiharbeit, Solo-Selbstständigkeit: Eine Bestandsaufnahme. Düsseldorf : Wirtschafts- und Sozialwissenschaftliches Institut (WSI).

12. Suprinovič, O., Schneck, St., \& Kay, R. (2016). Einmal Unternehmer, immer Unternehmer? Selbstständigkeit im Erwerbsverlauf. IfM-Materialien, 248.

13. Torsten, Kühlman, M., \& Haas, Hans-Dieter (2009). Internationales Risikomanagement: Auslandserfolg durch grenzüberschreitende Netzwerke. München : De Gruyter Oldenbourg.

\section{References}

1. Aliieva, E.Iu. (2017). Psykholohichni chynnyky formuvannia u studentiv zdatnosti do samostiinoho zhyttievoho vyboru [Psychological factors of formation of students' ability to make independent life choices]. Extended abstract of Candidate's thesis. Kyiv [in Ukrainian].

2. Karpov, A.V. (2003). Refleksivnost' kak psihicheskoe svojstvo i metodika ee diagnostiki [Reflexivity as a mental property and methods of its diagnosis]. Psihologicheskij zhurnal Psychological journal, 5, 45-56 [in Russian].

3. Kasvinov, S.G. (2013). Sistema Vygotskogo. Obuchenie i razvitie detej i podrostkov [Vygotsky's system. Education and development of children and adolescents]. Har'kov : Rajder [in Russian].

4. Kon, I.S. (1992). Psihologija samostojatel'nosti [Psychology of independence]. Pedagogika zdorov'ja - Health pedagogy, 268-273 [in Russian].

5. Krajg, G., \& Bokum, D. (2005). Psihologija razvitija [Developmental psychology]. SanktPeterburg : Piter [in Russian].

6. Osnickij, A.K. (2010). Psihologicheskie mehanizmy samostojatel'nosti [Psychological mechanisms of independence]. Moscow : Obninsk: IG-SOCIN [in Russian].

7. Tunik, E.E. (2002). Diagnostika lichnostnoy kreativnosti. [Diagnosis of personal creativity]. In N.P. Fetiskin, V.V. Kozlov \& G.M. Manuylov (Eds.), Sotsialno-psihologicheskaya diagnostika razvitiya lichnosti i malyih grupp - Socio-psychological diagnosis of personality development and small groups (p. 59-64). Moscow : Izd-vo Instituta psihoterapii [in Russian].

8. Bieri, P. (2017). Wie wäre es, gebildet zu sein? München/Grünwald : Verlag Komplett Media $\mathrm{GmbH}$.

9. Bland, J. (2013). Children's literature and learner empowerment: children and teenagers. London : Bloomsbury Academic.

10. Drieschner, E. (2007). Erziehungsziel „,Selbstständigkeit“. Grundlagen, Theorien und Probleme eines Leitbildes der Pädagogik. Wiesbaden : GWV Fachverlage GmbH.

11. Manske, A. \& Scheffelmeier, T. (2015). Werkverträge, Leiharbeit, Solo-Selbstständigkeit: Eine Bestandsaufnahme. Düsseldorf : Wirtschafts- und Sozialwissenschaftliches Institut (WSI).

12. Suprinovič, O., Schneck, St. \& Kay, R. (2016). Einmal Unternehmer, immer Unternehmer? Selbstständigkeit im Erwerbsverlauf. IfM-Materialien, 248.

13. Torsten, Kühlman, M., \& Haas, Hans-Dieter (2009). Internationales Risikomanagement: Auslandserfolg durch grenzüberschreitende Netzwerke. München : De Gruyter Oldenbourg. 


\title{
PSYCHOLOGICAL FEATURES OF THE DEVELOPMENT OF THE COGNITIVE COMPONENT OF INDEPENDENCE OF MODERN ADOLESCENTS
}

\author{
Liubov Dolynska
}

Ph.D in Psychology, Professor, Head of the Department of Psychology

National Pedagogical Dragomanov University

9, Pyrohov Str., Ukraine, Kyiv, 01601

Lbvdolinska@gmail.com, https://orcid.org/0000-0002-1817-1102

\author{
Daria Polishchuk \\ Postgraduate student of the Department of Psychology \\ National Pedagogical Dragomanov University \\ 9, Pyrohov Str., Ukraine, Kyiv, 01601 \\ daria_polishchuk@ukr.net, https://orcid.org/0000-0001-6400-624X
}

\begin{abstract}
The article substantiates the relevance and feasibility of studying the phenomenon of independence of modern adolescents. It is noted that the studied concept is a multicomponent formation, and, therefore, in its structure there are 4 components: cognitive, motivational-value, behavioral and emotional. This article is devoted to the study of the cognitive component of the phenomenon of independence of modern adolescents. The aim of the study is to determine the level of development of the cognitive component through its components - creativity, which characterizes a person's desire to generate new ideas and put them into practice, as well as constantly looking for opportunities for development and reflexivity, thanks to which the adolescent is able to realize the results of their own actions and deeds, summarize and, if necessary, adjust their actions in the right direction. The theoretical part presents an analysis of the main approaches of foreign and domestic scientists to the problem of development of the cognitive component of the phenomenon of independence in modern psychology. The peculiarities of the development of indicators of the cognitive component of creativity of modern adolescents are empirically determined, in particular, the peculiarities of curiosity, imagination, complexity of tasks and risk appetite are studied. The predominance of the average level of imagination, the complexity of the tasks, the propensity to risk, the component of curiosity is in the surveyed adolescents is above average, which is the age characteristic of adolescents. The level of development of reflexivity of modern teenagers is investigated and analyzed. The predominance of a low (which is characterized by difficulties in planning their activities, lack of ability to analyze their own mistakes, inability to use experience in solving difficult situations, difficulties in regulating their own behavior) and medium level of reflexivity (characterized by the ability to plan their actions and their analysis, as well as analysis of other people's actions, but reflexive processes are irregular, and reflexive analysis is superficial).

The significance of creativity and reflexivity as indicators of the cognitive component of creativity in the general structure of independence and its development during adolescence is substantiated.
\end{abstract}

Keywords: cognitive component, independence, self-regulation, creativity, imagination, intelligence, reflection, teenager. 